\title{
STUDY OF COMPONENTS OF HUBRISTIC MOTIVATION OF STUDENTS MAJORING IN PSYCHOLOGY
}

\section{Babatina S. I.}

\section{INTRODUCTION}

In consideration of individual success as the realization of certain goals set before the person, there arises the question of the nature of motivation for success, ways and means of such realization, which, in turn, are conditioned by the peculiarities of the personality orientation. Evolvement of a subject capable of conscious setting of life goals and their achievement, able to take responsibility for decision-making is determined by the behavioral strategy that is formed in the process of socialization. Such a behavioral strategy is determined by achievement motivation, which reflects values-based individual's attitude to himself/herself as a person and subject of activity.

The socio-economic situation is becoming more dynamic. The labor market is changing. Employers are interested in finding and selecting highly qualified personnel. Many graduates of professional educational establishments remain non-demanded as professionals, experiencing significant difficulties in practical application of the knowledge they have gained. In our opinion, this is determined by insufficient formation of the system of subjective regulation of activity, which characterizes a person not as a carrier of a certain set of professional knowledge, competences, skills, but as a professional, a subject of professional activity, who keeps its objectivity in a variety of changing circumstances and is capable of self-realization and selfdisclosure. Therefore, the issues of studying the subjective qualities of person, patterns and mechanisms of their development in the period of professional training are significant at the present stage of development of human society. Individual success involves the realization of certain goals set before the person, the developed motivation for success, the hubristic motivation in its two forms - the desire for superiority and excellence, which, in turn, appears to be connected with the peculiarities of the personality orientation. A number of components of personality orientation is formed by the 
main new formations of adolescence. This concerns, first of all, outlook, moral and professional self-determination etc.

The desire for self-affirmation as one of the components of the personality orientation underlies hubristic motivation and acts as one of the mail new formations of adolescence.

The process of development and evolvement of a student majoring in Psychology as a future specialist, in our time, attracts the attention of many theorists and practitioners of Psychology. The development of a student's personality takes place in conjunction with many situations that result in success or failure. Future professional activity determines the direction of personal development, influences the formation of interests, skills, percepts outlines the field of social expectations of the individual.

The study of the problem of personal need and motivational sphere of the student as a future psychologist and his/her desire for success is conditioned by the study of motivational tendencies as components of hubristic motivation, as a factor of desire for success. Hubristic motivation, which acts as an impetus for the personal development of a future psychologist, motivates his/her desire for personal growth, awareness of his/her inherent value as a psychologist, which creates the internal basis of professional training of a future specialist.

Analyzing the motivational sphere of an adolescent's personality the desire for success, self-esteem, perfection, we analyze the individual orientation, which determines the motivational tendencies for the desire for success, namely: motivation for success, perfectionism, hardiness, affiliation and others.

The desire for success of the individual ensures his/her professional and social self-affirmation and self-realization. Motivation for success makes students carry out their professional and personal advancement - from mastering the profession to achieving professional excellence and self-realization as a practitioner psychologist.

The basic algorithms for the behavioral solution of success achievement and failure avoidance problems are formed between the ages of three and thirteen. The nature of interdependence of activity and achievement motivation of the individual is determined by three areas: individual subjective perceptions of the likelihood of personal success and complexity of the task given to person; the degree of 
significance of this task for the subject and the strength of the desire to maintain and increase self-esteem; the tendency of a specific individual to adequately attribute to himself/herself, other people and circumstances the responsibility for success and failure.

Self-esteem and social expectations of the person, according to the modern scientist Ihor Popovych, is a two-way mutually agreed mechanism of mutual influences that fundamentally influences selfregulation of an individual's behavior. The scientist notes that social expectations are a link that combines the individual and the social in a personality, and play an active role in the processes of self-regulation of personality both in the behavioral and internally personal terms. Expectations are most often directly linked to the individual's moral standards, innovations in collective norms of behavior, and especially in the processes of self-education, self-affirmation, and selfimprovement ${ }^{1}$. These constructs, in the context of the topic raised, are the right ones for understanding and isolating the components of hubristic motivation of adolescents.

Although, hubristic motivation not only has a significant impact on the formation of the future psychologist's professionalism, but also forms one of the planes of his/her professional and life success, today there is a small amount of scientific research devoted to the study of these motivational aspects of personality. At the same time, it is worth noting that modern researches of scientists comprehensively reveal aspects of hubristic motivation through the system of self-affirmations of a person, his/her level of aspirations, self-esteem, professional and personal orientation, high hardiness, attitudes to victory and avoidance of failure, self-belief. The desire for self-affirmation, which underlies the hubristic motivation of the individual, is one of the main new formations of adolescence.

The objective of the problem raised is to outline the author's intention and to determine the components of the hubristic motivation of the individual to carry out a theoretical analysis of the motivational tendencies of the hubristic motivation of the personality striving for success. Following the determined objective, we plan to perform the following tasks and highlight results in paragraphs of the sections,

${ }^{1}$ Попович І.С. Психологія соціальних очікувань особистості : методологія, теорія і практика : навч.-метод. посіб. / І.С. Попович. - Херсон : ОЛДІ-ПЛЮС, 2019. - 158 с. 
namely: 1) to carry out theoretical analysis of motivational tendencies of a personality striving for success in the field of modern scientific and practical psychology; 2) to empirically determine the presence and nature of the relationship between motivational tendencies of hubristic motivation of adolescents, who strive for success.

The practical achievements of the conducted research will be useful for psychologists of secondary and higher education institutions in the field of youth outreach, in selecting a complex of methods for studying the student's personality orientation in the context of success motivation, in creating development programs aimed at developing constructive forms of hubristic motivation that may be applied in practice of psychological service of institutions of higher and secondary education, during training and professional development of practitioner psychologists.

\section{Theoretical analysis of the motivational tendencies of a personality striving for success in the field of modern scientific and practical psychology}

For the first time, the concept of hubristic motivations has been investigated by the Polish psychologist Józef Kozielecki. In his transgressive conception, hubristic motivation is central, and is seen by the author as a desire for self-affirmation, reinforcement and enhancement of the personality's self-esteem and self-importance, affirmation and increase of one's personal self-value. The scientist notes that a person always has the freedom of choice and controls his/her behavior. To achieve this goal, he/she goes beyond his/her own achievements and opportunities. In such conditions of personal growth, a person strives for high self-esteem of his/her activity. Therefore, the scientist defines hubristic motivation as a person's desire for affirmation and growth of self-value. According to J. Kozielecki, a person is a transgressive being who understands the conscious way of going beyond what he/she has and what he is. Transgression is a person's creative volitional ability and passion for overcoming boundaries. "People do not just carry out conservative acts aimed at 
preserving achievements and results. They try to go beyond what they have"2.

Psychological mechanisms of transgression are motivational processes that perform the functions that give impetus to action, cause the release of energy by the person, set the general direction of the search for value, support the action, affecting its duration. Motivational processes take place when the personality has two independent informations regarding the typical state and current state. Comparison of these informations and identification of differences drives motivation.

When referring to individual transgression as a hubristic motivation, J. Kozielecki refers to the case when the individual purposefully goes beyond his/her own possibilities, using creative selfaffirmation and personal self-actualization, as the main and ultimate goal of the individual's aspirations.

Problems of hubristic personality motivation were also considered by such scientists as S. Petrova, I. Pufal-Struzik, K. Savchenko, R. Tsvetkova, K. Fomenko, T. Khomulenko and others.

Thus, according to S. Petrova, hubristic motivation is the development of the individual, who strives for the achievements and superiority, perfection, implemented through the need in respect and authority among others, recognition, success and headship ${ }^{3}$; I. PufalStruzik defines hubristic motivation in the context of development, success, self-fulfillment in creative activities as desire for superiority and desire for excellence ${ }^{4} ;$ K. Savchenko substantiates that the problem of studying the motivational sphere of the individual is especially relevant in the current conditions of intensive scientific and technological development, including the context of higher education, when there occurs a formation and change of value orientations, reinterpretation of a person's place in society, understanding of responsibility for making decisions in the process of professional training and professional activity. The presence of a unified theory of

2 Козелецкий Ю. Человек многомерный (психологические эссе) Юзеф Козелецкий. - К. : Лыбидь, 1991. - 288 с. Козелецкий Ю. Человек многомерный (психологические эссе) / Юзеф Козелецкий. - К. : Лыбидь, 1991. - 288 с.

3 Петрова С.М. Мотивационная обусловленность Я-концепции личности в юношеском возрасте: Дис.... канд. психол. наук, - СПб., 1995. - 220 с.

${ }^{4}$ Пуфаль-Струзик И. Структурно-иерархическая модель творческой активности личности :дисс. ... д. психол. наук 19.00.01. М., 2003 . - 357 с. 
the motivational sphere of personality would allow to solve personal problems of self-realization of personality. Therefore, the scientist notes that the search for integrated characteristics of the motivational sphere of personality, which may have the purpose of establishing relationships between motives, may be useful on the way to the creation of such a motivation theory, while such characteristics themselves may be useful in the study of personality axiogenesis ${ }^{5}$; $\mathrm{R}$. Tsvetkova considers hubristic motivation in terms of the desire for power and success, which motivates the individual to self-fulfillment ${ }^{6}$; K. Fomenko associates hubristic motivation with psychological factors of success achievement, because success in achieving goals is conditioned by the degree of perfection of those qualities and skills that it requires. Also, the problem of hubristic motivation is central in the researches of the scientist and is considered in the structure of the orientation of the personality of students, who strive for success, towards excellence and perfection. She explored those peculiarities of the student-age personality orientation that are associated with the development of hubristic motivation ${ }^{78}$.

In the context of the topic we raised, the conducted analysis made it possible to determine that the development of the named qualities allows the person to strive for superiority and excellence through hubristic motivation. However, these aspirations may not always be the key to success. Hubristic motivation as the desire for superiority and

5 Савченко К. Взаємозв'язок показника мотивації успіху й рівня актуалізації особистісних мотивів у студентів і слухачів, що здобувають другу вищу освіту. Психологія особистості. 2013. No 1(4) с. 255-262. Савченко К. Взаємозв'язок показника мотивації успіху й рівня актуалізації особистісних мотивів у студентів і слухачів, що здобувають другу вищу освіту. Психологія особистості. 2013. № 1(4) с. 255-262. Савченко К. Взаємозв'язок показника мотивації успіху й рівня актуалізації особистісних мотивів у студентів і слухачів, що здобувають другу вищу освіту. Психологія особистості. 2013. № 1(4) с. 255-262.

${ }^{6}$ Цветкова Р.И. Мотивационная сфера личности современного студента: факторы, условия и средства ее формирования в процес се професіонального становлення: дис. ... докт. психол. наук. : 19.00.07 / Цветкова Р.И. - Хабаровск, 2007. - 433 с.

7 Фоменко К.І. Губристична мотивація в характеристиці спрямованості особистості / К.І. Фоменко // Наука і освіта: науково-практичний журнал Південного наукового Центру НАПН України. - Тематичний спецвипуск «Когнітивні процеси та творчість». - Одеса, 2010. - С. 378-381.

8 Фоменко К.I. Розробка та апробація методики «Діагностика губристичної мотивації» / К.І. Фоменко // Вісник Харківського національного університету ім. В.Н. Каразіна. Випуск 43. Серія: Психологія. - Харків: ХНУ, 2010. - № 902. C. 301-304. 
the pursuit of excellence is a very important component in the motivational sphere of the individual. Therefore, it is important to develop this construct at a young age, during the ontogenesis of the individual. This age is a sensitive period for the formation and setting of life program, life strategy, personality perspective, which allows a person to construct his/her future, see and feel the time perspective of his/her life and to model his/her actions according to his/her desires, needs and requirements of the environment, which are the main bricks of conscious formation of the regulatory outline of the personality ${ }^{9}$.

The study of personality orientation is carried out by studying the whole system of mental properties and states of personality: needs, interests, motivational sphere, ideals, values, beliefs, etc. Thus, orientation is a systematic property of the personality that determines its mental component.

Hardiness, as a construct of orientation of a person that strives for success, characterizes: an extent of that person's ability to withstand a stressful situation while maintaining internal balance; to overcome life's obstacles rather than avoid them; to act effectively against obstacles and difficulties that arise in personal and professional life; to be able to balance between the personal desire for a fulfilling, successful and harmonious personal life on the one hand, and the social expectations and demands of the environment on the other hand; to adapt to the new requirements while maintaining internal equilibrium and further striving for development ${ }^{10} 11$.

Heinz Heckhausen argues that, over the course of life, personality changes, and its hardiness either develops or improves, or remains undeveloped, indistinct. Cultivating his/her own hardiness, the personality developed and, while developing, did not stop at mastering something already prepared, established, familiar. Testing of new

9 Фоменко К.І. Шляхи та засоби розвитку губристичної мотивації студентів / К.І. Фоменко // Вісник Харківського національного університету ім. В.Н. Каразіна. Випуск 45. Серія: Психологія. - Харків: ХНУ, 2011. - № 937. - С. 285-287.

10 Ларіна Т. О. Життєстійкість особистості: соціальна необхідність та безпека // Життєстійкість особистості: соціальна необхідність та безпека // Т. М. Титаренко, Т. О. Ларіна. - К. : Марич, 2009. - 76 с.

11 Леонтьев Д. А. Тест жизнестойкости / Д. А. Леонтьев, Е. И. Рассказова // Методическое руководство по новой методике психологической диагностики личности с широкой областью применения. Предназначается для профессиональных психологовисследователей и практиков. - М. : Смысл, 2006. - 63 с. 
forms of interaction takes place at every life path; other options for response are produced, unexpected decisions appear ${ }^{12}$.

The motive is a reflection of a need that acts as an objective regularity, acts as an objective need to succeed. Also, the motive is something that motivates people to work, directing them to meeting specific needs. The motivational sphere of personality during adolescence is crucial both for evolvement of a person in general and as future specialist in a particular field. According to E. Klimov, personality is the subject of conscious productive activity and social behavior, an individual with a socially conditioned and individually peculiar system of mental properties, which is formed and manifested in activity, communication, and mediates, regulates human interaction with the surrounding world ${ }^{13}$.

T. Gordeeva notes that classification of social motives suggested by Murray is popular in foreign psychology. In his book "Explorations in Personality", Murray first identified the need for achievement. He described it as follows: "accomplish something difficult. To master, manipulate or organize physical objects, human beings or ideas. To do this as rapidly and as independently as possible. To overcome obstacles and attain a high standard. To excel one's self. To rival and surpass others. To increase self-regard by the successful exercise of talent". This is the setting that determines the movement toward selfactualization $^{14}$.

Also, there is a commonly accepted dispositional approach to the study of motivation suggested by D. McClelland. Human behavior is determined by the need or motive to achieve a specific goal (G). In achieving this goal, one can expect success (E+) or failure (E-). To achieve the goal, a person performs some instrumental activity (I) that either leads to the goal (I+) or not (I-). Sometimes, there are barriers,

${ }^{12}$ Хекхаузен Х. Мотивация и деятельность / Х. Хекхаузен. - 2е изд. - М. : Смысл, 2003. - 860 с. Хекхаузен Х. Мотивация и деятельность / Х. Хекхаузен. - 2е изд. - М. : Смысл, 2003. - 860 с. Хекхаузен Х. Мотивация и деятельность / Х. Хекхаузен. 2е изд. - М. : Смысл, 2003. - 860 c.

${ }^{13}$ Климов Е.А. Психология профессионала / Е.А. Климов // Избр. психол. труды. М. : Изд-во Моск. психолого-социального ин-та; Воронеж: НПО «МОДЭК», 2003. $456 \mathrm{c}$.

14 Гордеева Т.О. Психология мотивации достижения. Учебное пособие / Гордеева Т.О. - М. : Смысл; Изд. центр «Академия», 2006. - 333 с. Гордеева Т.О. Психология мотивации достижения. Учебное пособие / Гордеева Т.О. - М. : Смысл; Изд. центр «Академия», 2006. - 333 с. 
obstacles, which can be localized in the surrounding world (SOs) or in the person (POs) on the way to the goal. When performing activities to achieve this goal, a person feels a certain emotional condition, which can be positive $(\mathrm{C}+)$ or negative $(\mathrm{C}-)$. Sometimes someone helps a person $(\mathrm{H})$.

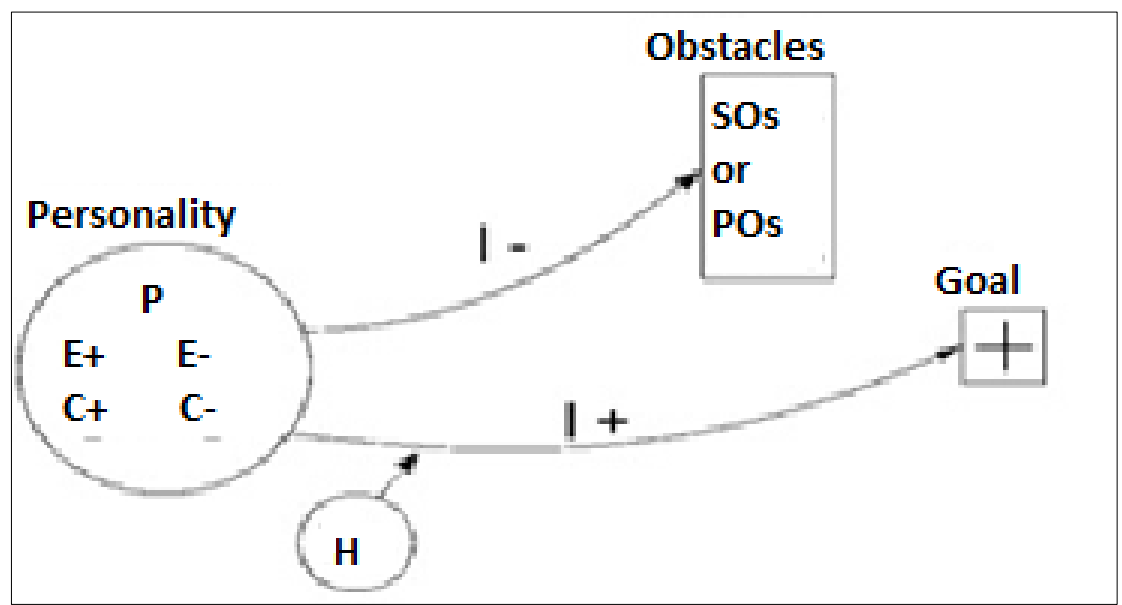

\section{Fig. 1. Scheme of formation of achievement motivation by D. McClelland}

In fact, the term achievement motivation was introduced by D. McClelland, who understood it as correlating with the quality of activity criterion. The scientist and his colleagues have developed a content analysis system to study the achievement-avoidance motivation, power motivation, affiliation motivation. They identified four motivational systems: power motivation, achievement and avoidance motivation, affiliation motivation. The first three systems are a reflection of the development of social motives of the individual; the fourth system is a reflection of the need for security. These systems are closely interconnected and each of the three motivational systems is influenced by the fourth. Any social motive may manifest itself in a «distorted» form (power motive - in the avoidance of responsibility; achievement motive - in the avoidance of failure; affiliation motive in fear of rejection) $)^{15}$.

${ }^{15}$ Макклелланд Д. Мотивация человека / Д. Макклелланд. - СПб. : Питер, 2007. 672 с. Макклелланд Д. Мотивация человека /Д. Макклелланд. - СПб. : Питер, 2007. $672 \mathrm{c}$. 
On the way to perfection, the individual sets high requirements to himself and others, which sometimes may interfere with the achievement of the final successful result. If we speak scientifically, we are talking about such a personal property as perfectionism. Perfectionism, as a motivational determinant of the desire for success, is the desire to be perfect, flawless. Perfectionism acts as the driving force of the individual for ensuring personal, professional and social success, for improving professional skills, for self-improvement and self-realization both personal and professional, for self-actualization. Self-actualization is the leading basis of personality that drives and directs people to activity, to development, to achieving acme. Perfectionism, as the driving force of personality development, may act as an obstacle to professional activity and self-actualization of the personality $^{16} 17$.

It is important, in the context of the topic analyzed, to pay attention to the affiliation motive of the individual in his/her desire for success, because it is an inducement, a mental activity that aims at establishing specific interpersonal relationships, which may in a certain amount of time become peculiar for the individual and «transform» in personality traits (properties). Affiliation motivation, from the perspective of the personality that strives for it, may be defined as acceptance, desirability of self, friendly support and sympathy, as a mutual and trusting relationship, in the presence of which each partner treats the other kindly, accepts him/her, supports and sympathizes him/her in a friendly manner.

The need for communication of emotional and trusting nature, and the focus on affiliative behavior are two components of the affiliation motivation, while «fear of rejection» is a quite independent variable and may determine the specificity of communication and has a close relationship with anxious conditions, uncertainty, level of psychological protection.

${ }^{16}$ Гаранян Н. Г. Психологические модели перфекционизма / Н. Г. Гаранян // Вопросы психологии. - 2009. - № 5. С. 74-78.

${ }^{17}$ Гаранян Н.Г., Низовцева А.А. Структура мотива достижения у студентов с разным уровнем перфекционизма [Электронный ресурс] / Н.Г. Гаранян, А.А. Низовцева // Психологическая наука и образование: электрон. журн. 2012. № 1. - Режим доступа: http:// psyedu.ru. 
We agree with the contemporary researcher in the field of hubristic motivation, Karina Fomenko, who argues that the affiliation motive for a student majoring in Psychology is an inducement, a mental activity aimed at establishing specific interpersonal relationships. In a certain amount of time, it may become peculiar for the personality and «transform» into personality traits, which in turn will improve the professional skills of the student majoring in Psychology in his/her professional development ${ }^{18}$.

Generalizing the approaches of scientists to the study of the need and motivational sphere of personality, in the topic discussed, we are particularly interested in hubristic motivation not only as the desire to avoid failure, but in general, the movement towards excellence and perfection. In this perspective, hubristic motivation in psychological science shall mean striving of a personality for self-esteem and growth of self-importance. Hubristic motivation has two forms - the pursuit of superiority and the pursuit of excellence ${ }^{19}$.

We present the main components investigated in the outlined topic and summarized as a result of theoretical analysis in Fig. 2.

The pursuit of superiority and the pursuit of excellence are associated with the psychological factors of success because the success sought by the individual requires certain skills, qualities and abilities, which this person masters and which certain circumstances of life activity require.

Thus, motivation is what allows a person to move determinedly in the context of life prospects and to succeed in the chosen activity - be it a professional field or other activity, and in personal life as well. Also, the above-mentioned motivational tendencies: pursuit of success - avoidance of failures, perfectionism, hardiness, affiliation influence the person's desire for success. We consider these

18 Фоменко К.І. Шляхи та засоби розвитку губристичної мотивації студентів / К.І. Фоменко // Вісник Харківського національного університету ім. В.Н. Каразіна. Випуск 45. Серія: Психологія. - Харків: ХНУ, 2011. - № 937. - С. 285-287. Фоменко К.І. Шляхи та засоби розвитку губристичної мотивації студентів / К.І. Фоменко // Вісник Харківського національного університету ім. В.Н. Каразіна. Випуск 45. Серія: Психологія. - Харків: ХНУ, 2011. - № 937. - С. 285-287.

${ }^{19}$ Хомуленко Т. Б., Фоменко К. І. Губристична мотивація як чинник прагнення до успіху: віковий аспект / Т. Б. Хомуленко, К.І.Фоменко. - Харків : ХНПУ, 2012. - 222 с. Хомуленко Т. Б., Фоменко К. І. Губристична мотивація як чинник прагнення до успіху: віковий аспект / Т. Б. Хомуленко, К.І.Фоменко. - Харків : ХНПУ, 2012. - 222 с. 
motivational tendencies in the context of our research as constituent components of hubristic motivation, which are inherent in the individual in his/her pursuit of success, in enhancing his/her level of perfection and skillfulness.

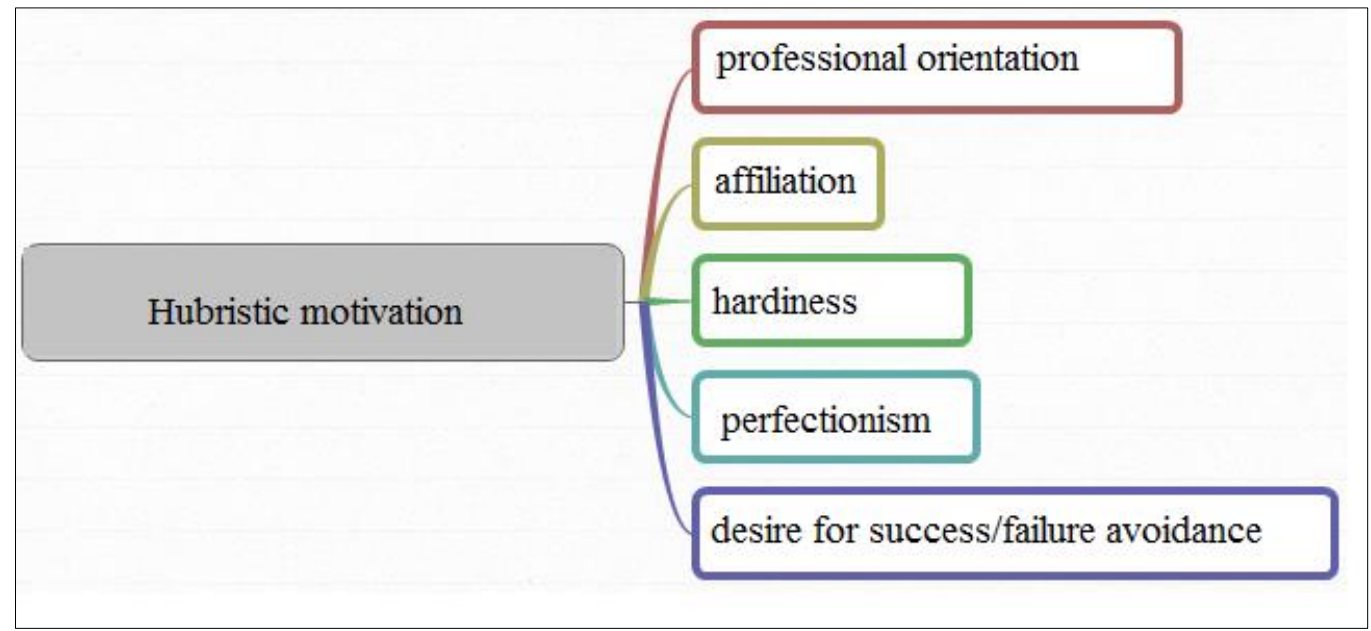

Fig. 2. Components of hubristic motivation

Thus, analyzing the results of scientific research, we can argue that hubristic motivation is one of the components of the motivational sphere of adolescents, who strive for success in both professional and personal life, and forms a personal orientation for the further development and self-realization of the individual. In turn, orientation of the individual is the formation that determines the life program and conscious movement towards the goals, and, the main thing, subjective vision of a perspective lifeline from the platform of adolescence.

Thus, adolescence is sensitive to the formation of hubristic motivation in the system of personal orientation of adolescents. Personality orientation of an individual involves formation of those qualities that motivate and ensure achievement of success in a certain type of activity, and helps to get personal, social and professional maturity.

Thus, adolescence is a period of striving to increase one's selfesteem and self-importance, the pursuit of superiority over others, and the pursuit of perfection in the full spectrum of young person's activities. 


\section{Empirical research of the nature of communication between motivational tendencies of hubristic motivation of adolescents striving for success}

Research methods: To achieve the objectives and solve the tasks set, the following methods of research were applied: theoretical (theoretical analysis of scientific research sources, comparison and generalization of scientific data, interpretation of modern theoretical and empirical research in psychology) and empirical (psychodiagnostic test of motivational trends of a person, personality orientation, regulatory personality traits) and mathematical statistics methods to process the results.

Sample and research methods characteristics. An empirical sample of our study consisted of 26 students of Socio-Psychological Faculty at Kherson State University, specialty «Psychology», aged 18 to 25 .

The following psycho-diagnostic methodologies were used to achieve this goal:

1. «S. Maddi Hardiness Survey» Methodology. Adaptation by D.A. Leontyeva, E.I. Rasskazova ${ }^{20}$. The survey is aimed at diagnosing the psychological factors of successful stress management, as well as reduction and prevention of internal stress in a stressful situation.

2. Bass Orientation Inventory. This methodology helps to revel the following directions orientations:

1) Self-orientation - the focus on direct reward and satisfaction regardless of work and employees, aggressiveness in achieving status, bossiness, aptitude for rivalry, irritability, anxiety, introversiveness.

2) Interaction-orientation - the desire to maintain relationships with people under any circumstances, focus on joint activities, which often interferes with performance of specific tasks or provision of sincere help to people, orientation to social approval, dependence on the group, need for commitment and emotional relationships with people.

20 Леонтьев Д. А. Тест жизнестойкости / Д. А. Леонтьев, Е. И. Рассказова // Методическое руководство по новой методике психологической диагностики личности с широкой областью применения. Предназначается для профессиональных психологовисследователей и практиков. - М. : Смысл, 2006. - 63 с. 
3) Task orientation - interest in solving business problems, work performance in the best possible way, focus on business cooperation, ability to defend one's own opinion in business interests, which is useful to achieve a common goal ${ }^{21}$.

3. Ehlers' Motivation to Success Test (methods of personality diagnostics for motivation to success and for motivation to avoid failures $)^{22}$. The questionnaire is designed to diagnose a person's motivational orientation for success.

\section{Multidimensional Perfectionism Scale by P.L. Hewitt and} G.L. Flett (adaptation by I.I. Grachyova). Diagnostic scale for measuring the level of perfectionism and determining the nature of the ratio of its components. Three components of perfectionism are described: self-oriented perfectionism (SOP) - (setting too high standards of activity); other-oriented perfectionism (OOP) - (setting too high demands for others); socially prescribed perfectionism (SPP) - (individual's believe that others hold unrealistic expectations for his/her behavior $)^{23}$.

5. Affiliation Motivation (AFM) methodology by A. Megrabyan (modified by M.Sh. Magomed-Eminov). The methodology allows us to evaluate how successful contacts with strangers will be; predict behavior when making new acquaintances and joining a new team; diagnostics of two generalized persistent personality motives that are part of the affiliation motivation structure: desire for acceptance (DA) and fear of rejection (FR), to measure the intensity of these indicators ${ }^{24}$.

Analysis of the results of empirical research. In order to study the need for affiliation motivation of students majoring in Psychology and its impact on future professional activity, we conducted an empirical study using the Affiliation Motivation (AFM) methodology by A. Megrabyan. Analyzing the results of two generalized persistent

${ }^{21}$ Карелин А. Большая энциклопедия психологических тестов / А. Карелин. - М. : Эксмо, 2007. - 416 с. Карелин А. Большая энциклопедия психологических тестов / А. Карелин. - М. : Эксмо, 2007. - 416 с.

${ }_{22}$ Розанова В.А. Психология управления // Методика диагностики мотивации к достижению успеха Т. Элерса / В.А. Розанова. - М., 1999. - С. 105-106.

23 Грачева И.И. Уровень перфекционизма и содержание идеалов личности: автореф. дис. ... канд. психол. наук. - М.: ИП РАН, 2006. - 24 с.

${ }_{24}$ Фетискин Н.П. Социально-сихологическая диагностика развития личности и малых групп / Н.П. Фетискин, В.В. Козлов, Г.М. Мануйлов. - М. Изд-во Института Психотерапии. $-2002 .-490$ с. - С. 70-72. 
personality motives that are part of the affiliation motivation structure: desire for acceptance and fear of rejection, we found that $11 \%$ of respondents have a low level of desire for acceptance motivation and $89 \%$ of respondents have an average level of desire for acceptance motivation; indicators of fear of rejection motivation show $3 \%$ of low level of development of this motive and 3\% of high level of development of this motive, while the rest $-94 \%$ have an average level of development of this motive (Fig. 3).

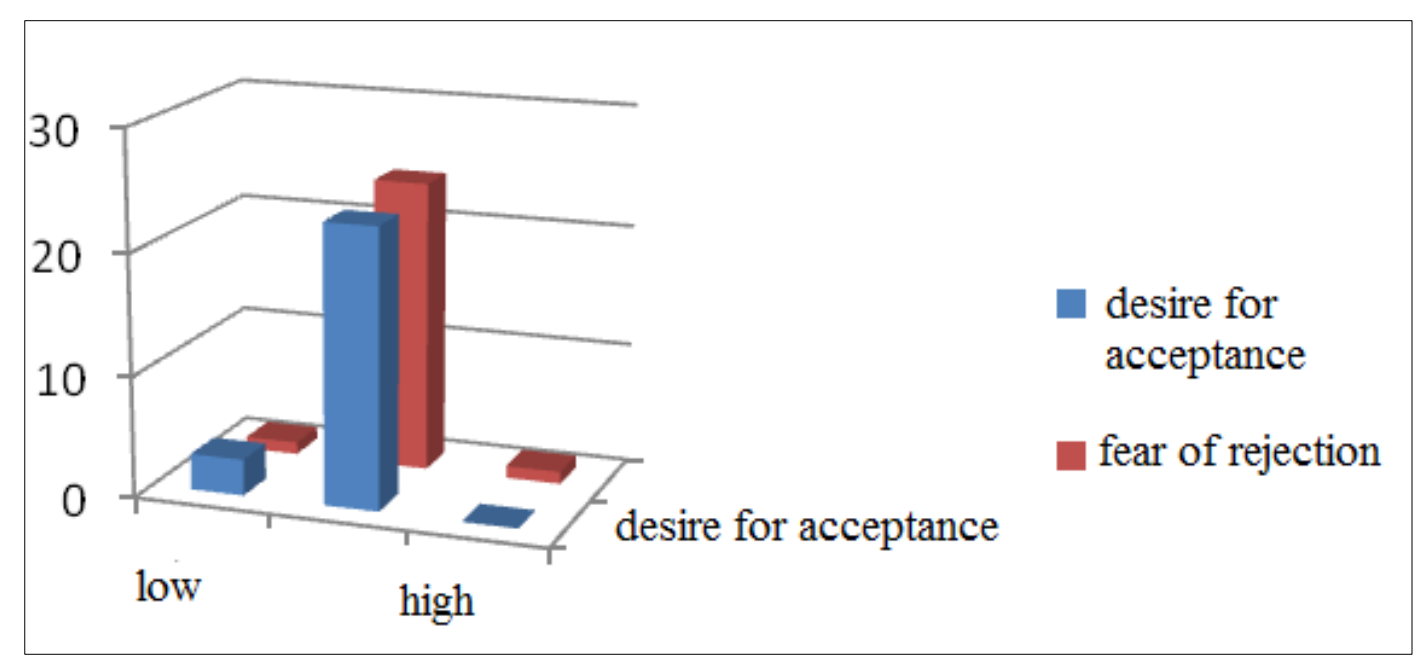

Fig. 3. Distribution of results of the studied students by affiliation motivation

As we can see from the results obtained that an average level of desire for acceptance motivation and an average level of fear of rejection motivation are inherent in most students. Affiliation motivation, in the context of our research, determines professional orientation. However, it is possible to assume that the students under study may contextually "turn on" both desire for acceptance motivation and fear of rejection motivation depending on the desire for communication, or avoidance of communication, seeking solitude. This may also indicate the presence of stress in the studied students, as fear of rejection prevents meeting the need for affiliative communication with other individuals. $11 \%$ of those surveyed showed low desire for acceptance motivation and relatively high fear of rejection index. This indicates that students have internal discomfort, stress, and impediment to meeting the need to be in the company of others. According to our result, students with a high level of development of the fear of rejection (3\%) actively avoid interaction 
with people and seek solitude. If the sum of points on the scale of desire for acceptance is more than that on the scale of fear of rejection, the respondents express a desire for affiliation. In our case, $3 \%$ of the respondents have a low level of indicators of fear of rejection motivation and a high level of desire for acceptance motivation, which is manifested in the desire to communicate with other people, interact with them, give help, support and receive it from others. Therefore, the average level of development of affiliation motivation is peculiar for the students majoring in Psychology included in our sample, which indicates that the need to create trusting, warm, emotionally meaningful relationships is essential for them, that the affiliation motivation contributes to success in evolvement of a professional psychologist as a component of hubristic motivation.

Based on the results of "S. Maddie Hardiness Survey", we found that the hardiness component makes 76.4 points for the studied students majoring in Psychology, which indicates the average level of offence of hardiness and its components, in the professional and personal direction. Hardiness in general prevents the emergence of internal stress, makes it possible to maintain internal peace in stressful situations. Through the use of coping behavior and certain coping strategies, these individuals have the potential and ability to overcome both internal and external obstacles that arise in personal and professional life to achieve their goal. It is also important to have pronounced components of hardiness to maintain normal mental health, optimal levels of performance, activity in stressful conditions. In our study, we determine the vulnerability of hardiness in general, and the individual differences of each of the three components constituting hardiness of the subjects of research.

It was found that the average level of such a component of hardiness as control predominates in $58 \%$ of students. It allows you to control your life, your activities, your needs and motives. Personality affects the results of his/her hardiness and the choice of the activity that he/she likes. This makes it possible to strive for success and achieve it, to enjoy both professional and personal life. 35\% of respondents have a high level of control. This is an indicator of almost ultimate control of a person over his/her destiny. It is in his/her hands, but it does not prove that a person achieves success, a positive, emotionally colored result because total control causes stress, worries and inability to get pleasure from the result. $8 \%$ of respondents have a 
low level of control - a state of their own powerlessness, inability to influence the course of life, and as a result - lack of successful professional and personal life (Fig. 4).

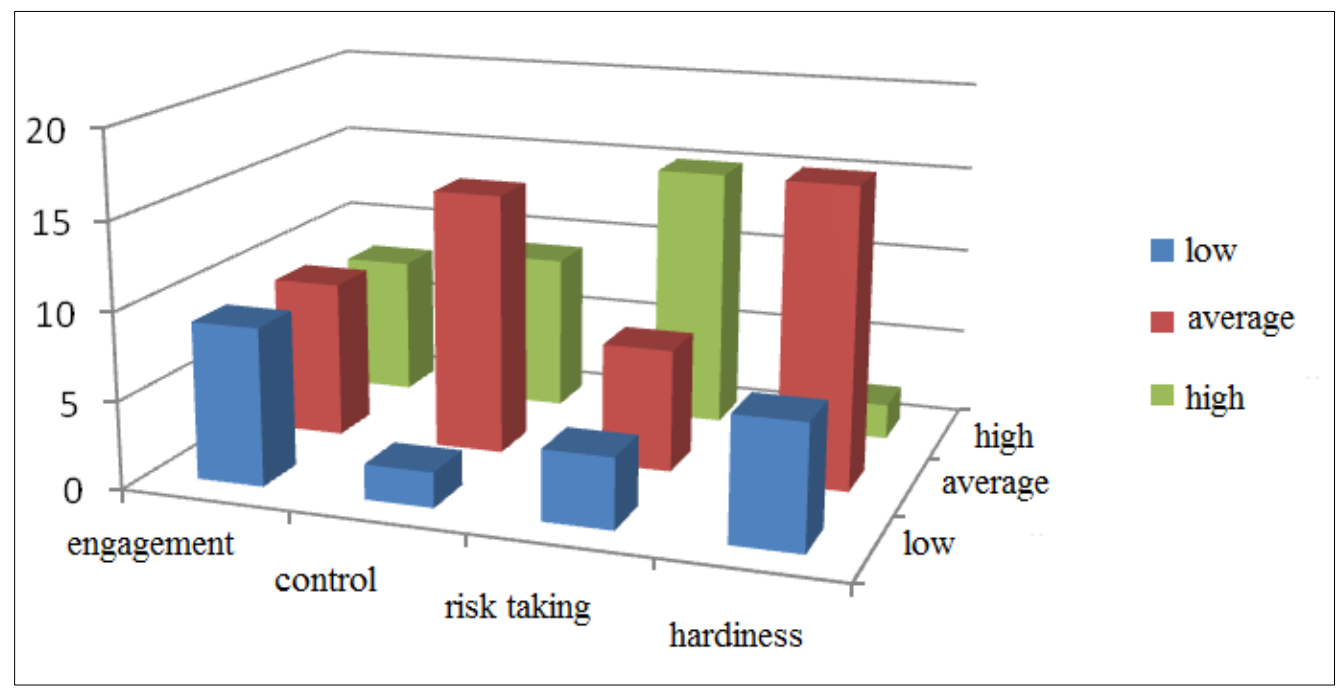

\section{Fig. 4. Distribution of results of the studied students by the test for hardiness and its components}

Using the Pearson correlation coefficient $\left(r_{p}\right)$, we determined the inverse relationship between the criteria of control, hardiness component, and self-orientation, professional orientation of the individual, $(\mathrm{r}=-0,40, \mathrm{p} \leq 0,05)$. Self-orientated personality is focused on direct reward and satisfaction irrespective of work and employees. Self-orientated personality may be aggressive in achieving status, power, he/she is prone to rivalry, which leads to conflict, irritability, anxiety, and as a consequence - inability to control and influence his/her live, to be the master of the destiny. Control, unlike selforientation, promotes the development and formation of goals achievement strategies, ability to overcome difficulties, control one's cravings and desires that do not contribute to personal victories. It helps future psychologists to achieve success in education and future professional activity.

Contrary to control, hardiness component - risk taking is of high level in $58 \%$ of students, which shows acceptance of both positive and negative experiences as a way to absorb knowledge, experience and desire to act even without guarantees of success. This component has a positive effect on professional orientation of students majoring in Psychology, because it provides the opportunity to form and develop 
hubristic motivation as striving for superiority and desire for excellence for a successful future professional activity as a practitioner psychologist. The striving for superiority is manifested in reinforcement of one's self-esteem, thereby securing one's place among others in interpersonal rivalry. The desire for excellence, as a form of hubristic motivation, is manifested in improvement of one's self-esteem through the constant improvement of one's achievements, enhancement of the level of perfection, and the pursuit of skillfulness.

Hardiness component engagement rates are distributed as follows: 35\%:35\%:0\%. It should be noted that such a distribution distinguishes a third of students with low engagement rates. That is, these students are not interested in the fact that this feature helps to find new knowledge, discover new, better prospects for development and be involved in the midst of events, both educational and professional, enjoy their own activities, as the other third of respondents feel it. To feel confident, satisfied both professionally and personally means to direct your activity to the professional direction, forming a hubristic motivation for successful professional and personal development and, consequently, to turn one's own desire for success into professional and personal success.

Perfectionism is a specific personality trait that manifests itself in young people's desire for excellence and social success. In 19\% of students surveyed, the level of self-oriented perfectionism is high, and characterizes the personality as too demanding, too self-critical, who carries out constant evaluation of himself/herself, which makes it impossible to accept his/her own defects, shortcomings and failures. The level of such perfectionism does not contribute to the success of a person because dissatisfaction with one's results, a high level of requirements for oneself does not contribute to the completion of actions, interpersonal interaction, satisfaction with oneself, positive evaluation of oneself as a specialist or personality. $54 \%$ of students involved in the research have an average level of perfectionism, which is characterized by moderate demands to themselves, acceptance of themselves, their own shortcomings, failures, which help a person to become a better specialist in his/her business and generally enable him/her to develop and succeed (Fig. 5). 


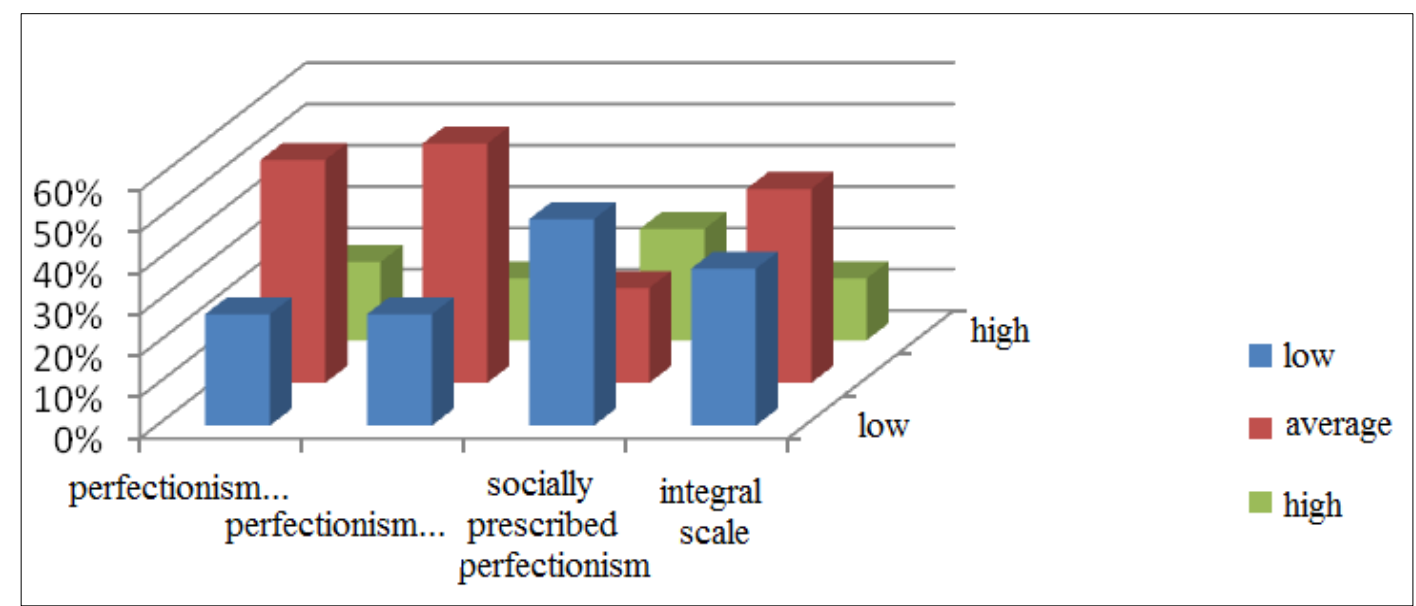

Fig. 5. Manifestation of perfectionism components in students of different levels of perfectionism

Other-oriented perfectionism in most students involved in our sample meets the average level (58\% of the students studied), which allows the individual to demand perfection, professionalism from others, making moderate demands, and to understand their shortcomings or failures.

Socially prescribed perfectionism is of low level in 50\% of students, which characterizes a person as independent of the evaluations and opinions of others and self-focused. A person with such characteristics is able not only to strive for success, but also to achieve it because he/she does not depend on the evaluation of others, his/her desire for and achievement of superiority and excellence do not depend on the environment because he/she has his/her own understanding of the criteria for success. Expressiveness of a general level of perfectionism in professional orientation of students is average. This shows their desire for excellence in education and further professional activity, and their desire to be the best in the profession. Perfectionism of this level influences the formation and development of hubristic motivation, as one of the components of successful professional activity.

Pearson correlation coefficient $\left(r_{p}\right)$ was used to investigate the peculiarities of the connection of the components of the need and motivational sphere of personality as components of hubristic motivation. The result is a direct relationship between self-oriented perfectionism (SOP) and task orientation $(r=0.49$, at $p \leq 0.01)$ and an inverse relationship between aspiration for interaction (affiliation motivation) and self-oriented perfectionism (SOP) $(\mathrm{r}=-0.48$, at 
$\mathrm{p} \leq 0.05$ ), between aspiration for interaction and the general level of perfectionism $(r=-0.41$, at $\mathrm{p} \leq 0.05)$. An inverse relationship was also found between control and self-orientation $(r=-0.40$, at $p \leq 0.05)$, between fear of rejection and engagement $(r=-0.42$, at $\mathrm{p} \leq 0.05)$, between fear of rejection and control $(r=-0.38$, at $\mathrm{p} \leq 0.05)$, between fear of rejection and hardiness $(r=-0.40$, at $\mathrm{p} \leq 0.05)$.

Self-oriented perfectionism (SOP) correlates positively with task orientation $(\mathrm{r}=0.49$, at $\mathrm{p} \leq 0.01)$. The obtained correlation shows that a person sets himself/herself high demands, constantly conducts selfassessment of his/her behavior, shows interest in solving business problems, performs work in the best way, focusing on business cooperation. The person is able to defend his/her opinion in interests of the business, which is useful for achieving a common goal, and strives to carry out business in the best possible way, and to be flawless in the eyes of others, to gain excitement and respect of others for his/her excellence.

Thus, during the empirical study, it was found that students with task orientation and self-oriented perfectionism have the opportunity to succeed in their chosen business, to strive for superiority and excellence, both personal and professional, to strive for self-fulfillment and self-actualization of personality, as a component of competitive motivation.

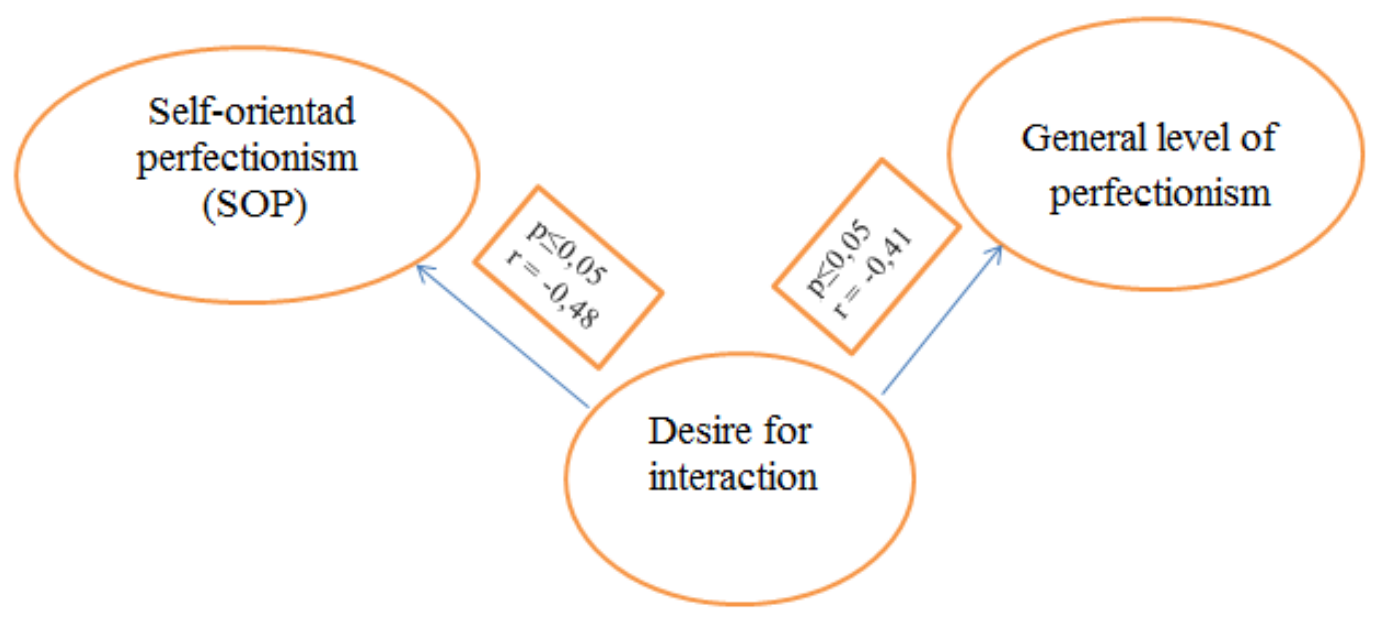

\section{Fig. 6. Correlation pleiade of the connection of the studied indicators}

Figure 6 shows correlation pleiade of the connection of the studied parameters: desire for interaction and self-oriented perfectionism, 
desire for interaction and general level of perfectionism. The desire for interaction correlates negatively with self-oriented perfectionism (SOP) $(\mathrm{r}=-0.48$, at $\mathrm{p} \leq 0.05)$. The obtained correlation indicates that the desire for interaction involves active search for contacts and communication with them, not imposing high demands to himself/herself, feeling mainly positive emotions, which conflicts with self-oriented perfectionism: inflated, unrealistic demands to himself/herself. Therefore, it makes it impossible to accept his/her own shortcomings and failures, mistakes that may manifest in communication and will not allow to be a full participant in interpersonal interaction. Consequently, non-acceptance of his/her own failure postpones the achievement of perfection and excellence in personal development.

The desire for interaction correlates negatively with the general level of perfectionism $(r=-0.41$, at $\mathrm{p} \leq 0.05)$. The obtained correlation shows that the person that desires for interaction not only constantly strives for people and feels pleasure from constructive, effective, emotionally positive communication with them, but also sees one of the meanings of life in human interpersonal relations. Thus, at high general level of perfectionism (when a person tends to impose extremely high demands to himself/herself, others, and regard the demands set for him/her by others as inflated and unrealistic), an individual cannot meet his/her need in communication. Thus, the general level of perfectionism makes productive interpersonal communication, which arises at desire for interaction, impossible. In order to achieve perfection, the demands set to himself/herself and others have to be high, and therefore, hubristic motivation has to correlate positively with perfectionism and its manifestations.

Figure 7 shows correlation pleiade of the connection of the studied parameters: fear of rejection and engagement, fear of rejection and control, fear of rejection and hardiness.

Fear of rejection correlates negatively with engagement $(r=-0.42$, at $\mathrm{p} \leq 0.05$ ). Engagement is a person's confidence in the possibility and importance of active participation in the events of his/her life, in the ability to find interesting and subjectively significant things through active search. Fear of rejection is manifested by uncertainty, inhibitedness, which causes mistrust and feeling that he/she has poor communication skills, or if a person realizes that someone has tried to humiliate or use him/her to meet someone else's needs. This may 
affect his/her affiliation needs. Thus, the correlation shows that the need for communication, support, understanding remains unmet and the person goes into the world of his/her worries. An internal conflict arises in a person: he/she strives for communication, active actions and at the same time avoids them.

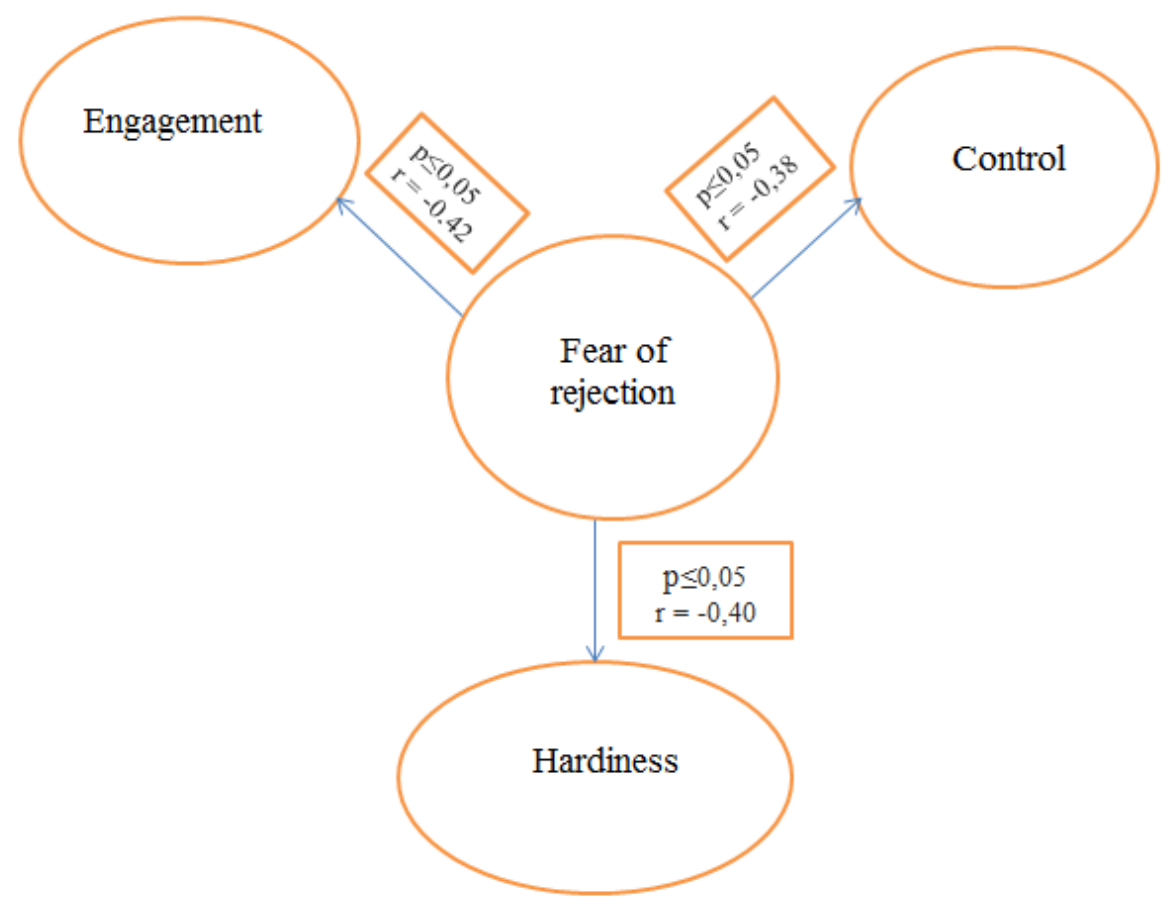

\section{Fig. 7. Correlation pleiade of the connection of the studied indicators}

Fear of rejection inversely correlates with control $(r=-0.38$, at $\mathrm{p} \leq 0.05$ ). The correlation obtained shows that control implies the belief that a person can control what is happening to him/her, control and influence changes in life in the desired direction. With fear of rejection, the person shows lack of self-confidence and confidence in others. The person treats others with suspicion and avoids them, which impedes interpersonal interaction, and results in inability to satisfy the need for productive communication, which prevents him/her from verifying the chosen behavioral strategy and nature of reactions to a difficult or dangerous situation in the form of reactions to his/her actions by others. Thus, the fear of rejection prevents the individual from controlling and influencing the changes in his/her life in the desired direction and being successful in the profession.

Fear of rejection negatively correlates with hardiness in general $(\mathrm{r}=-0.40$, at $\mathrm{p} \leq 0.05)$. Hardiness is a system of ideas about oneself, the 
world and relationships with it, which prevents the emergence of internal stress in stressful situations, and helps to overcome stress. The person is actively involved in life, activity; he/she controls himself/herself, the situation, influences the course of events, adequately perceives obstacles and looks for ways to overcome them. Fear of rejection is the result of those seeking solitude and avoiding interpersonal interaction. It may indicate the presence of a person's internal discomfort, stress or personal anxiety, which leads to a decrease in human hardiness, inability to withstand stresses and tensions that occur in the interpersonal communication. The correlation obtained shows that the fear of rejection leads to a decrease in human hardiness, the inability to withstand stress, the inability to overcome obstacles o the way to professional and personal success.

Thus, during the empirical study, it was found that the desire for success, self-esteem, excellence is determined by motivational tendencies, namely: motivation for achieving success/avoiding failure, perfectionism, hardiness, affiliation, etc., which are components of hubristic motivation.

In the context of the topic, we determined that perfectionism as a motivational determinant of the desire to succeed may act as the driving force of personality to provide personal and professional success, but may also serve as an obstacle to professional activity and self-actualization. Hardiness, as a construct of the personality striving for success helps to overcome vital obstacles, which also contributes to personal success. Affiliation motivation as a desire for interaction and motivation for success are manifested in the desire to move, to improve professional skills in the chosen field of activity and contribute to the success of the individual. By contrast, the affiliation motivation such as fear of rejection, and failure avoidance motivation do not lead the person towards professional or personal success, but contrarily hinder its achievement.

\section{CONCLUSIONS}

Conducted theoretical analysis and empirical research of the problem raised allows us to sum up the information and draw conclusions.

1. Motivational sphere of personality during adolescence is crucial for evolvement of a person in general and of a future specialist in his/her business. Personality with predominating motivation for 
success shows the desire to move up, to improve professional skills, to excel in the chosen field of activity. Adolescence is sensitive to the development of personality motivational tendencies in the subjective dimension.

2. Having analyzed the motivational tendencies of students majoring in Psychology during their studies at a higher education institution, motivational tendencies of the desire for success have been determined, namely: motivation for success achievement/failure avoidance, perfectionism, hardiness, affiliation, and professional orientation as constituents (components) of hubristic motivation, which enable an individual to achieve success and superiority in life. Hubristic motivation is the desire for superiority and the desire for excellence. The desire for superiority is manifested in reinforcement of one's self-esteem, thereby securing one's place among others in interpersonal rivalry. The desire for excellence, as a form of hubristic motivation, is manifested in enhancement of one's self-esteem through the constant improvement of one's achievements, enhancement of the level of perfection, and the pursuit of skillfulness.

3. We have empirically determined the nature of the connection between the motivational tendencies of hubristic motivation of adolescents striving for success. In the context of the study, it was found that there are both direct and inverse correlations between the components of hubristic motivation, which may both contribute to and hinder the success of the individual. Therefore, we can point out that hubristic motivation as the desire for superiority and the desire for excellence cannot be a factor in the desire for success, but may only determine the individual trajectory of movement of the subject's own life.

\section{SUMMARY}

The author of the study conducted a scientific and theoretical discourse on the determination and justification of components of hubristic motivation of an individual. The author has conducted an empirical study of a set of components that determine the desire for excellence and success in the sample of students who have chosen practical psychology as their field of studies. It was empirically determined that there is a connection between hubristic motivation and perfectionism. Desire for excellence and hubristic motivation in general are the driving force of perfectionism. The more the 
personality is oriented towards success and self-affirmation, the higher his/her requirements to himself/herself are and the higher the desires are, because the desire for success, as well as the desire for self-esteem and self-affirmation act as characteristics of motivational sphere of a person, who strives for success. Therefore, students who strive for perfection in their activities, such as achieving a certain harmony, are aimed at achieving such harmony in their relations with society as well.

It is substantiated that adolescence is a sensitive period of the subjective movement of the individual in the set of regulatory and motivational tendencies and determination of personal and professional potentials. The practical value of research for practitioner psychologists has been claimed.

\section{REFERENCES}

1. Попович I.C. Психологія соціальних очікувань особистості : методологія, теорія і практика : навч.-метод. посіб. Херсон : ОЛДІ-ПЛЮС, 2019. 158 с.

2. Козелецкий Ю. Человек многомерный (психологические эссе) К.: Лыбидь, 1991. 288 с.

3. Петрова С.М. Мотивационная обусловленность Я-концепции личности в юношеском возрасте: Дис.... канд. психол. наук, СПб., 1995. 220 с.

4. Пуфаль-Струзик И. Структурно-иерархическая модель творческой активности личности :дисс. ... д. психол. наук 19.00.01. М., 2003. 357 с.

5. Савченко К. Взаємозв'язок показника мотивації успіху й рівня актуалізації особистісних мотивів у студентів і слухачів, що здобувають другу вищу освіту. Психологія особистості. 2013. No 1(4) c. 255-262

6. Цветкова Р.И. Мотивационная сфера личности современного студента: факторы, условия и средства ее формирования в процессе профессионального становлення: дис. ... докт. психол. наук. : 19.00.07 Хабаровск, 2007. 433 с.

7. Фоменко К.I. Губристична мотивація в характеристиці спрямованості особистості. Наука і освіта: науково-практичний жсурнал Південного наукового Центру НАПН Украӥни. Тематичний спецвипуск «Когнітивні процеси та творчість». Одеса, 2010. С. 378-381. 
8. Фоменко К.I. Розробка та апробація методики «Діагностика губристичної мотивації». Вісник Харківського національного університету ім. В.Н. Каразіна. Випуск 43. Серія: Психологія. Харків: ХНУ, 2010. № 902. С. 301-304.

9. Фоменко К.І. Шляхи та засоби розвитку губристичної мотивації студентів. Вісник Харківського національного університету ім. В.Н. Каразіна. Випуск 45. Серія: Психологія. Харків: ХНУ, 2011. № 937. С. 285-287.

10. Ларіна Т. О., Титаренко Т. М. Життєстійкість особистості: соціальна необхідність та безпека. К. : Марич, 2009. 76 с.

11. Леонтьев Д. А., Рассказова Е. И. Тест жизнестойкости. Методическое руководство по новой методике психологической диагностики личности с широкой областью применения. Предназначается для профессиональных психологовисследователей и практиков. М.: Смысл, 2006. 63 с.

12.Хекхаузен Х. Мотивация и деятельность. 2е изд. М. : Смысл, 2003. 860 с.

13.Климов Е.А. Психология профессионала. Избр. психол. труды. М. : Изд-во Моск. психолого-социального ин-та; Воронеж: НПО «МОДЭК», 2003. 456 с.

14.Гордеева Т.О. Психология мотивации достижения. Учебное пособие. М.: Смысл; Изд. центр «Академия», 2006. 333 с.

15. Макклелланд Д. Мотивация человека. СПб.: Питер, 2007. $672 \mathrm{c}$.

16. Гаранян Н. Г. Психологические модели перфекционизма. Вопросы психологии. 2009. №5. С. 74-84.

17.Гаранян Н.Г., Низовцева А.А. Структура мотива достижения у студентов с разным уровнем перфекционизма [Электронный ресурс]. Психологическая наука и образование: электрон. журн. 2012. № 1. Режим доступа: http:// psyedu.ru.

18. Фоменко К.І. Шляхи та засоби розвитку губристичної мотивації студентів. Вісник Харківського національного університету ім. В.Н. Каразіна. Випуск 45. Серія: Психологія. Харків: ХНУ, 2011.- № 937. С. 285-287.

19. Хомуленко Т. Б., Фоменко К. І. Губристична мотивація як чинник прагнення до успіху: віковий аспект [Монографія]. Харків : ХНПУ, 2012. 222 с.

20. Леонтьев Д. А., Рассказова Е. И. Тест жизнестойкости. Методическое руководство по новой методике психологической 
диагностики личности с широкой областью применения. Предназначается для профессиональных психологов-исследователей и практиков. М.: Смысл, 2006. 63 с.

21.Карелин А. Большая энциклопедия психологических тестов. М. : Эксмо, 2007. 416 с.

22. Розанова В.А. Психология управления. Методика диагностики мотивации к достижению успеха Т.Элерса М., 1999. С. $105-106$.

23.Грачева И.И. Уровень перфекционизма и содержание идеалов личности: автореф. дис. ... канд. психол. наук. М.: ИП PAH, 2006. $24 \mathrm{c}$.

24. Фетискин Н.П., Козлов В.В., Мануйлов Г.М. Социальносихологическая диагностика развития личности и малых групп. М. Изд-во Института Психотерапии. 2002. 490 с. С. 70-72.

\section{Information about the author:} Babatina S. I.

Candidate of Psychological Sciences, Associate Professor, Associate Professor at the Department of General and Social Psychology, Kherson State University 27, Universytetska str., Kherson, 73000, Ukraine 